\title{
Salon 女䁌堵し-Iッ甘1
}

\section{女性研究者と研究者夫婦}

\section{松永真理子（中央大学理工学部）}

\section{1.はじめに}

私は，2008年に早稲田大学で博士取得後，ハーバード 大学 (米国) における博士研究員等を経て，2012 年に中 央大学に異動し, 私立大学の教員として講座を立ち上げ 研究を続けています。

本題に移る前に折角の機会ですので研究経緯を手短か に紹介させていただきます。学生時代は自己組織化単分 子膜修飾電極の電気化学を中心に検討し, 電気化学セン サ応用（主にキラルセンサ）を目指した研究を行ってき ました。留学時は材料科学を学習し, 自己組織化単分子 膜を使ったナノ・マイクロ材料の自己集合現象の制御方 法を研究しました。現在は電気電子情報通信工学科に所 属していますが，電気化学に関する講義を担当しており， 研究の方も電気化学を軸に保ちながら, 化学センサや各 種電池に利用が期待される三次元複合電極の作製と特性 評価を中心に実験を行っています，現状で出来ることを 進めながらも，もっと新しいことに取り組めないものか と考えているところです。

本エッセイは学生の頃よりお世話になっている電気化 学会からの依頼でしたので，迷わず引き受けましたが， 性別を意識せずに活動してきた場で女性研究者として エッセイを書くという作業は予想外に難しく, 中々筆が 進まず苦労しました。記憶を辿り直すと現職着任後は大 学教員として男女共同参画に向けて，これから理系の素 養を生かして活躍し得る女性を応援する役割を担うこと が増えてきていることを思い出しました。今回は，女性 研究者になるまでの経緯と留学時代の経験を紹介し, “理 系女”を（も?）応援する女性研究者としての私感を述べ たいと思います。

\section{2. 女性研究者になるまで}

大学受験に向けて将来を考元始めた 1990 年代後半は, そ水以前と比較し女性の生き方も多様化し始めていたよ うに思います。性別を強く意識する機会も特に無かった ため，大学における専攻を選ぶ際には得意な理系科目を 武器に大学受験をして入れる専攻の中で一番魅力的に見 えたという理由で理工学部に進学を決めました。

私が進学した早稲田大学理工学部応用化学科は, 女性 は約 20 人，割合は全体の 1 割強でした。「気をあまり使わ ずに話せる居心地が良い仲間が多い」という印象を持った 記憶があります。理系を選択したという共通点から価值観 や考え方に類似点が多かったのかもしれません. 女性が少 なくて嫌だなと思ったことは一度もありませんでした。

研究室は，物理化学に興味を持ち逢坂哲爾教授主幸の 応用物理化学研究室を選択しました。何に引き寄せられ
たのか，卒業生には芯のある自立した女性が多い研究室 です，卒業研究に取り組む中で，自分で考えたことを元 に何かを創る作業にやりがいを感じたことや国際的な活 動に魅力を感じたことから，これらの経験が続けられる 恵まれた環境にもう少し居たいと思い, アカデミックの 職業を視野に入れて博士後期課程進学を決めました.

博士号取得後, 進学を決めた時の海外への強い思いは 変わらず, 博士研究員として自己組織化や生体模倣材料 の研究に力を入れているハーバード大学の Joanna Aizenberg 教授の研究室にてアメリカ留学を実現しました. 学ぶ楽しさを出し惜しみせずに提供するハーバード大学 と, 学ぶ意欲のある学生が作り出すパワフルでクリエイ ティブな環境に大変感動しました。アメリカの研究室も 日本と同様に多種多様ですが, 博士研究員と博士学生の 人数比で雾囲気が多少なりとも予測できるのではないか と思います。私の所属した研究室は博士研究員の人数が 多い, 結果重視の研究室でした。研究室自体も立ち上げ 直後の過渡期で, 博士研究員を自由に競争させる環境で した。研究に関して言えば博士研究員に先輩後輩も男女 も関係無く，更に手段も然程問わ机ずとにかく結果を出 した者勝ちなので，うかうかしてられません．刺激的な 生活でしたが, 信頼のおける友人にも恵まれ，精神も鍛 えられました。また，飛び抜けた研究の力こそが強く， そして私の価值観に打いて美しく生きる糧となることを 認識する良い経験になりました。写真(Fig. 1) は2009年の 夏頃に Aizenberg group で撮った写真です。2007年に新設 された研究室です，大勢写っていますが，Joanna（ボス）, 研究室立ち上げメンバーの博士研究員 7 名と博士学生 3 名

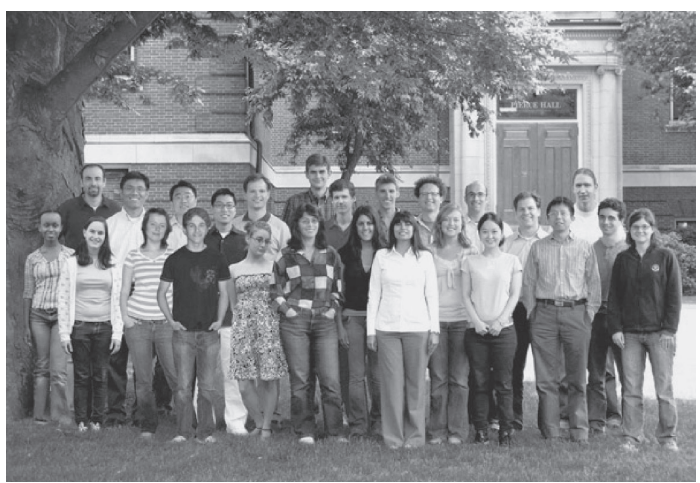

Figure 1. Aizenberg 研究室のメンバーとの写真. 筆者は前列 右から 3 番目. 夏期休暸期間に撮影したため, 沢山の visiting studentsが一緒に写っています（撮影時インターンシップ等 で不在した学生は, 写真撮影担当学生により画像処理で挿入 されています)。 


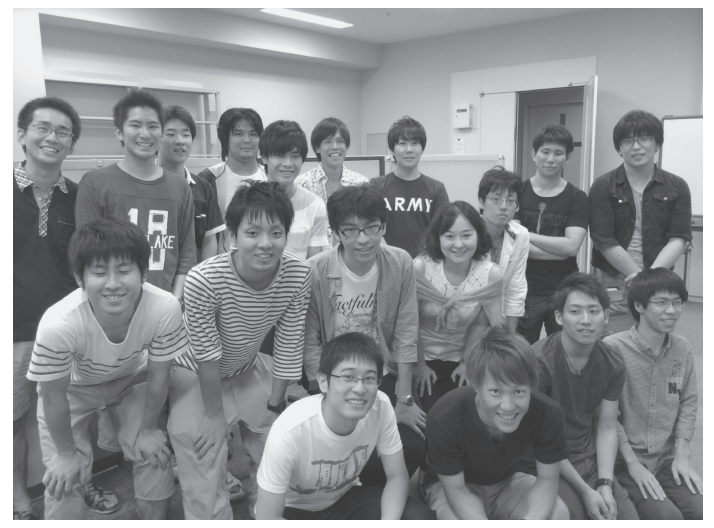

Figure 2. 現在の研究室メンバー（一部）との写真。筆者は 2 列目左から 4 番目.

がコアメンバーでその他は夏の期間だけ研究室に参加し た高校生, フランスからの短期留学生, 学部生が写って います。私が留学中に既に 2 倍程に人数が増えていまし たが, 現在ではコアメンバーだけで 50 名程度の研究室に なっているようです。

その後, 日本の大学に就職し, 当初の希望通りアカデ ミックの研究者として一歩を踏み出しました.「アメリカ は良い場所だった」と言うと「アメリカに残る選択肢は 無かったのか」と聞かれることがあります。これに関し ては留学前より大好きな日本に戻ることを想定していた せいか，日本を軸にして活動することに何一つ抵抗はあ りませんでした。写真 (Fig. 2) は残念ながら全員写ってい ませんが，2014年の夏休み前の納会に現在の研究室メン バーで撮ったものです。今年は学部生 11 名, 修士学生 13 名, そして私の計 25 名で活動しています。このエッセイ の内容から話は逸れますが, 講座自体が新規立ち上げで あったため, 着任後から現在まで担当講義数や研究室の 学生数が倍増し続けています。ペースを掴み難い日々が 続いています。

\section{3. アメリカで見た研究者夫婦について}

我が家は夫婦共にアカデミックに身をおく研究者です。 分野は違えども，いつでも相談ができ，自然に相手を思 いやることや支え合うことが出来るため良い決断だった と思っています。早稲田大学時代に同級生であった夫と は，アメリカでは同じ時期に向かいの建物に位置する 別々の研究室で働く博士研究員仲間でした。現在は東京 と大阪に離れ，単身赴任生活を余儀なくされています.

最近日本の女性管理職比率の低さが話題になっていま すが, 女性研究者も増加傾向ではあるものの, 2013 年に 過去最高の $14.4 \%$ と先進国の中では圧倒的に低い值と なっています。日本より女性研究者の割合の高いアメリ カでは沢山の研究者夫婦に出会いました。折角ですので, 一番身近であった二組の夫婦を紹介したいと思います。
一組目は私のアメリカでのボスとその夫です。夫婦共に イスラエルの超エリート校, ワイッマン科学研究所で博 土号を取得しており, 妻はアメリカのベル研で, 夫は企 業で研究者として働いていました。ジョアナが前職であ るベル研を退職し，ハーバード大学の教授に着任すると 夫は会社を辞め, 妻らが率いる同大学の研究機構の研究 員になり，夫は妻の研究室の研究や行事に参加するよう になりました。二人は公私共に良きパートナーで，妻の ジョアナは世界中の研究者が集まる有名研究室を築き, 現在アメリカで大活躍されています。二組目は私の夫の 留学先のボスであった教授とその妻です。この夫妻は夫 婦共にハーバード大学の教授でした．夫婦の長年のチー ムワークを生かして共同研究をするなど，こちらも公私 ともに良きパートナーとして活躍されていました，大変 な愛妻家で得意げに妻の話をする様子が忘れられません. 競争社会において信頼のおける仲間が大切であること， また夫婦が一番の仲間になれることを近くで拝見できた ことは, 研究者夫婦として生きていく上で非常に重要な 経験でした。

\section{4.おわりに}

1 で述べましたように, 研究の場であまり女性であるこ とを意識せずに過ごしてきたので, 女性研究者として何 を書くべきか大変悩みました. 結局, とてもプライベー 卜な事に触れる結果になってしまいました。しかしなが ら “理系女”応援イベントに携わるようになり, 女性の理 系進学後の将来を心配するご家族がいることを知りまし た.このため, 大学ではオープンキャンパス等を通じて, 理系や “理系女”の人生を身近に感じていただく機会を増 やしています。本エッセイも情報を必要としている方の 参考になればと思い, 執筆させていただきました。特に 日本では女性の社会進出もまだまだ過渡期です。性別に 限りませんが (例えば世代等), 異なる分類に対して, つ い非建設的で否定的な発言をしてしまうことがあります. 自分の所属する分類に対し, 自分に当てはまらない誤っ た決め付けをされていると残念な気持ちになるので, 私 自身も不必要にこのような発言をしないように気をつけ たいと思っています。今後は女性のみならず留学生数も 増えていくと思います。女性が仕事を持てば，男性の家 庭での役割も多様化します。他の先進国に遅ればせなが ら, 多くの方がこれらの多様性を受け入れ, 活用してい ける時代となることを期待しています。

最後になりますが, これまで電気化学会の学会やシン ポジウム等を通じて沢山の先生方にご助言や激励をいた だきました。おかげでなんとか研究を続けられています. この場を借りて改めて心よりお礼申し上げます。今後と もご指導の程, 宜しくお願い申し上げます。また，この ようなリレーエッセイに登場する機会を下さいまして, ありがとうございました。 